\title{
Effects of phosphorus and organic fertilizers on phosphorus fractions in submerged soil
}

\author{
F. Abolfazli, A. Forghani and M. Norouzi* \\ Department of Soil Science, Faculty of agriculture, University of Guilan, Iran. Postal card: 41635-1314, phone: \\ +989111386 159,fax: + 981316690 281. *Corresponding author:mehdi_uni2000@yahoo.com
}

\begin{abstract}
This study was conducted in order to evaluate effects of phosphorous fertilizer (PF)s from sources of triple superphosphate (TSP) and di-ammonium phosphate (DAP) and organic fertilizer (OF)s from sources of cow dung manure (CDM) and municipal solid waste compost (MSWC) on phosphorous (P) fractions include aluminium$\mathrm{P}$ (Al-P), iron-P (Fe-P), Reductant soluble-P (RS-P), calcium-P (Ca-P) and available-P (Olsen-P) fractions under rice cultivation condition. The trials were carried out in calcareous and acidic soils. PFs were added at three levels (10, 20 and $30 \mathrm{mg}$ $\mathrm{kg}-1)$ and OFs was applied at the rate of 10 t.ha $^{-1}$. Results of this study showed that $\mathrm{Ca}-\mathrm{P}$ was the predominant form of $\mathrm{P}$ in calcareous soil while Fe-P and Al-P were predominate in acidic soils. In calcareous soil, all forms of $\mathrm{P}$ under submerged conditions had been increased because of using PFs both alone and in combination with OFs. In acidic soil, significant amounts of $\mathrm{P}$ fractions were found only in Fe-P and RS-P fractions. Accordingly, Fe-P fraction increased in $10 \mathrm{mg} \mathrm{kg}^{-1}$ treatment and RS-P increased in MSWC treatment. Among the inorganic P fractions in calcareous soil, only RS-P; and in acidic soil, Ca-P and Fe-P significantly correlated to Olsen-P.

Keywords: Cow dung manure; Dose rate; Municipal solid waste compost; Phosphorus fractions; Rice
\end{abstract}




\section{Introduction}

Phosphorus (P) plays the same chemical and biochemical role in plants as it does in all other organisms. It is the main element involved in energy transfer for cellular metabolism and it is a structural component of cell membranes, nucleic acids, and other critical materials (Wiedenhoeft, 2006). Information on the chemical forms of $\mathrm{P}$ is fundamental to understand $\mathrm{P}$ dynamics and its interactions in calcareous and acidic soils which are necessary for management of P. Jalali and Ranjbar (2010) observed the reactions of $\mathrm{P}$ added to the calcareous soils were quite rapid and water-soluble phosphate was converted to relatively less soluble compounds within a very short time due to high sorbing capacities of the soils. P transformations in flooded soils depend on soil characteristics that may affect $P$ availability. $\mathrm{P}$ is generally most available to plants when the soil $\mathrm{pH}$ is between 6.0 and 6.5. When the soil $\mathrm{pH}$ is $<6.0$, the potential for $\mathrm{P}$ deficiency increases for most of crops. Phosphate ions readily precipitate with metal cations, forming a range of $\mathrm{P}$ minerals. The type of mineral formed will depend on the soil $\mathrm{pH}$ in the first place as it governs the occurrence and abundance of those metal cations that are prone to precipitate with $\mathrm{P}$ ions in the soil solution, namely $\mathrm{Ca}, \mathrm{Fe}$ and $\mathrm{Al}$. Hence, in neutral to alkaline soils, $\mathrm{P}$ ions will rather precipitate as Calcium phosphorus (Ca-P): dicalcium or octacalcium phosphates, hydroxyl apatite and eventually least soluble apatites (Hinsinger, 2001). Increasing of $\mathrm{pH}$, depending on the buffering capacity of the water column, precipitate a significant portion of water column $\mathrm{P}$ as $\mathrm{Ca}-\mathrm{P}$ where dissolved $\mathrm{Ca}$ is available (Reddy et al., 1999).

In acidic soils, the soil $\mathrm{P}$ is bound in compounds, such as $\mathrm{Fe}$ and $\mathrm{Al}$ phosphates, which are essentially insoluble under aerobic or upland conditions (Sanchez and Uehara, 1980; Slaton et al., 2002). Organic acids produced by microorganisms or plant roots react with $\mathrm{Fe}$ and $\mathrm{Al}$ through chelate formation (Bhattacharyya et al., 2005). Under reduced, anaerobic conditions, Fe plays a major role in $\mathrm{P}$ dynamics. Reduction of $\mathrm{Fe}$ and its re-precipitation to form ferrous $\left(\mathrm{Fe}^{2+}\right)$ minerals are dominant processes under anaerobic conditions (Rhue and Harris, 1999).

Rice (Oryza sativa), one of the most important crops in the world and Iran is cultivated under submerged conditions. When soil is submerged, air is excluded and the soil quickly becomes anoxic and reduced. This phenomenon changes physical, biological, and chemical properties of soil (Singlachar and Samaniego, 1973) such as redox potential. Changes in redox potential as induced by plant roots in the rhizosphere can thus be responsible for changes in pH (Hinsinger, 2001). This has been clearly demonstrated by Begg et al. (1994) for lowland rice, who estimated that the root-induced oxidation of its rhizosphere contributed a significant or even major proportion of the measured rhizosphere acidification. Although the rice requirement for inorganic P (consisted of $\mathrm{P}$ associated to $\mathrm{Fe}, \mathrm{Al}$ and $\mathrm{Ca}$ oxides and hydroxides or clay minerals) is much less than that for $\mathrm{N}$, the continuous removal of $\mathrm{P}$ exploits the soil $\mathrm{P}$ reserve if the soil is not replenished through fertilizer or manure application. Therefore, $\mathrm{P}$ is added to cultivated soils worldwide through chemical or organic (e.g., manure and sewage sludge) fertilization. When a water-soluble Phosphorous fertilizer (PF) such as triple superphosphate (TSP) or di-ammonium phosphate (DAP) is applied to soil, immediately after its dissolution the phosphate ions in solution react with $\mathrm{Ca}, \mathrm{Fe}$, or $\mathrm{Al}$ ions present in soil solution and are precipitated as insoluble compounds, or become adsorbed on surface of clay particles (Prasad and Power, 2000). Chemical P fertilizer is a costly agri- 
cultural input for rice farmers in Iran, and sometimes the material is not available. At this time, cow dung manure (CDM) may be considered as an alternative to chemical P fertilizer. Saleque et al., 2004 were reported that $\mathrm{CDM}$ can be a potential source of $\mathrm{P}$. Bhattacharyya et al. (2005) were reported that the dominant $\mathrm{P}$ fraction in municipal solid waste compost (MSWC) and CDM was organic matter bound $P$ (organic $\mathrm{P}$ ) followed by $\mathrm{P}$ bound to $\mathrm{Fe}$ and $\mathrm{Al}$ oxides. Soil $\mathrm{P}$ availability was increased with the addition of MSWC, Fe and Al may contribute significantly to $\mathrm{P}$ bioavailability in submerged soil by enhancing the cation-exchange capacity and reducing the $\mathrm{P}$ fixation (Knapp et al., 2002).

The objectives of this research were to evaluate effects of phosphorous fertilizer (PF) (in dose rate (DR)s 0, 10, 20 and $30 \mathrm{mg} \mathrm{kg}^{-1}$ ) and organic fertilizer (OF) on $\mathrm{P}$ fractions such as aluminum phosphorous (Al-P), iron phosphorous (Fe-P), reductant soluble phosphorous (RS-P), Ca-P, available phosphorous (Olsen-P), under rice cultivation condition in calcareous and acidic soils.

\section{Material and methods}

\subsection{Soil sampling and pot experiment}

This study was carried out at greenhouse condition in Guilan Agricultural University (length of day 12 h, day average temperature $25^{\circ} \mathrm{C}$, night average temperature $16^{\circ} \mathrm{C}$ and mean humidity $75 \%$ in experiment duration). Soil samples were obtained from two sites, Rostam Abad ( $36^{\circ} 57^{\prime} \mathrm{N}$ latitude and $49^{\circ} 26^{\prime} \mathrm{E}$ longitude) and Fashalem ( $37^{\circ} 15^{\prime} \mathrm{N}$ latitude and $49^{\circ} 25^{\prime}$ E longitude) in Guilan Province, north of Iran. Soil samples were collected from surface layer $(0-30 \mathrm{~cm})$. These soils had alkali reaction in Rostam Abad site (with $\mathrm{pH}=7.33$ measured in $\mathrm{H}_{2} \mathrm{O}$ ) and acidic reaction in Fashalem site (with $\mathrm{pH}=3.34$ measured in $\mathrm{H}_{2} \mathrm{O}$ ). The soil samples were air-dried and ground to pass through a $2 \mathrm{~mm}$ sieve for laboratory experiments. Available phosphorus (Olsen-P) was determined by using 0.5 M sodium bicarbonate solution at $\mathrm{pH}=8.5$ (Olsen's extractant) (Kuo, 1996). Table 1 shows some physical and chemical characteristics of used soils.

Table 1. Some physical and chemical characteristics of used soils.

\begin{tabular}{|c|c|c|c|c|c|c|c|c|c|c|c|c|}
\hline \multirow[b]{2}{*}{ Site } & \multicolumn{2}{|c|}{$\mathbf{p H}$} & \multirow{2}{*}{$\begin{array}{c}\text { EC } \\
\left(\text { ds. }^{-1}\right)\end{array}$} & \multirow{2}{*}{$\underset{\left(\mathrm{g} \mathrm{kg}^{-1}\right)}{\mathbf{O M}}$} & \multirow{2}{*}{$\begin{array}{c}\text { Equiva- } \\
\text { lent } \\
\mathrm{CaCO}_{3} \\
\left(\mathrm{~g} \mathrm{~kg}^{-1}\right)\end{array}$} & \multicolumn{3}{|c|}{ Texture $\left(\mathrm{g} \mathrm{kg}^{-1}\right)$} & \multirow{2}{*}{$\begin{array}{c}\text { Soil } \\
\text { Texture } \\
\text { class }\end{array}$} & \multirow{2}{*}{$\begin{array}{c}\text { Available } \\
\mathbf{P} \\
\left(\mathrm{mg} \mathrm{kg}^{-1}\right)\end{array}$} & \multirow{2}{*}{$\begin{array}{c}\text { Calcium } \\
\text { Phosphate } \\
\left(\mathrm{mg} \mathrm{kg}^{-1}\right)\end{array}$} & \multirow{2}{*}{$\begin{array}{c}\mathrm{CEC} \\
\left(\mathrm{Cmol}^{+} \text {. }\right. \\
\left.\mathrm{kg}^{-1}\right)\end{array}$} \\
\hline & $\mathrm{H}_{2} \mathrm{O}$ & $\begin{array}{c}0.01 \mathrm{M} \\
\mathrm{CaCl}_{2}\end{array}$ & & & & Clay & Silt & Sand & & & & \\
\hline $\begin{array}{l}\text { Rostam } \\
\text { Abad }\end{array}$ & 7.33 & 7.43 & 3.5 & 22.5 & 180 & 662 & 267 & 71 & $\mathrm{C}$ & 51.6 & 171.37 & 36.73 \\
\hline $\begin{array}{l}\text { Fasha- } \\
\text { lem }\end{array}$ & 3.34 & 3.54 & 1.4 & 136.5 & 5 & 342 & 167 & 491 & SCL & 158 & 28.165 & 30.40 \\
\hline
\end{tabular}

EC- electrical conductively; OM- organic matter; CEC- cations exchange capacity.

Plastic pots having $22 \mathrm{~cm}$ height and $20 \mathrm{~cm}$ opening mouth diameter were selected. Approximately, five kilograms of air-dried soil passed through a $4.8 \mathrm{~mm}$ sieve was added to each plastic pot (126 pots). PFs such as TSP and DAP were used at three levels (10,
20 and $30 \mathrm{mgP}^{-\mathrm{kg}^{-1}}$ ). PF was added to soil alone or in combination with organic fertilizers (OF). Two OFs such as, MSWC and CDM were applied at the rate of $10 \mathrm{t} / \mathrm{ha}$. Some characteristics of OFs are showed in Table 2 . The pots submerged immediately after adding 
amendments and the soil moisture was held at almost saturation percentage during the first three days with constant mass of pots by adding water (as gravimetrically), and then four germinated rice seeds (Oryza sativa L. cultivar Tharam) were transplanted in each pot. The rice seeds were sterilized in hypochlorite solution (1\%). The soils were kept in submerged condition throughout period of experiment. After 30 days, soil samples were collected from each container and analyzed for the different fractions of $\mathrm{P}$.

Table 2. Some characteristics of organic fertilizer (OF).

\begin{tabular}{lccccc}
\hline Organic fertilizer type & $\mathbf{p H}$ & $\begin{array}{c}\mathbf{E C} \\
\left(\mathbf{d s} . \mathbf{m}^{-1}\right)\end{array}$ & $\begin{array}{c}\mathbf{O M} \\
\left(\mathbf{g ~ k g}^{-1}\right)\end{array}$ & $\begin{array}{c}\text { Calcium } \\
\left(\mathbf{C m o l}^{+} . \mathbf{k g}^{-1}\right)\end{array}$ & $\begin{array}{c}\text { Available P } \\
\left.\mathbf{( m g ~ k g}^{-1}\right)\end{array}$ \\
\hline Municipal solid waste compost* (MSWC) & 7.35 & 7.11 & 464 & 26.3 & 167.41 \\
Cow dung manure (CDM) & 6.09 & 5.35 & 286 & 19.5 & 720 \\
\hline
\end{tabular}

${ }^{*}$ This compost is produced in Lakani Company. EC- electrical conductively; OM- organic matter.

\subsection{Sequential phosphorus fractionation}

All soil samples were analyzed for P fractions using Kuo (1996) procedure. In this procedure, soil $\mathrm{P}$ fractions are sequentially extracted on the basis of their relative solubilities in extractants. Fractionation schemes utilize the complexing ability of $\mathrm{F}^{-}$from am- monium fluoride $\left(\mathrm{NH}_{4} \mathrm{~F}\right)$ to separate $\mathrm{Al}-\mathrm{P}$ form $\mathrm{Fe}-\mathrm{P}$ in acidic soil, followed by removal of $\mathrm{Fe}-\mathrm{P}$ with $\mathrm{NaOH}$ and of the RS-P with sodium citrate $\left(\mathrm{Na}_{3} \mathrm{C}_{6} \mathrm{H}_{5} \mathrm{O}_{7}\right.$. $\left.\mathrm{H}_{2} \mathrm{O}\right)$ - sodium dithionate $\left(\mathrm{Na}_{2} \mathrm{~S}_{2} \mathrm{O}_{4}\right)$ - sodium bicarbonate $\left(\mathrm{NaHCO}_{3}\right)(\mathrm{CDB})$ extractions. The $\mathrm{Ca}-\mathrm{P}$, which is insoluble in $\mathrm{CDB}$, is extracted with $\mathrm{H}_{2} \mathrm{SO}_{4}$ and $\mathrm{HCl}$ in acidic and calcareous soils, respectively (Figure 1). 


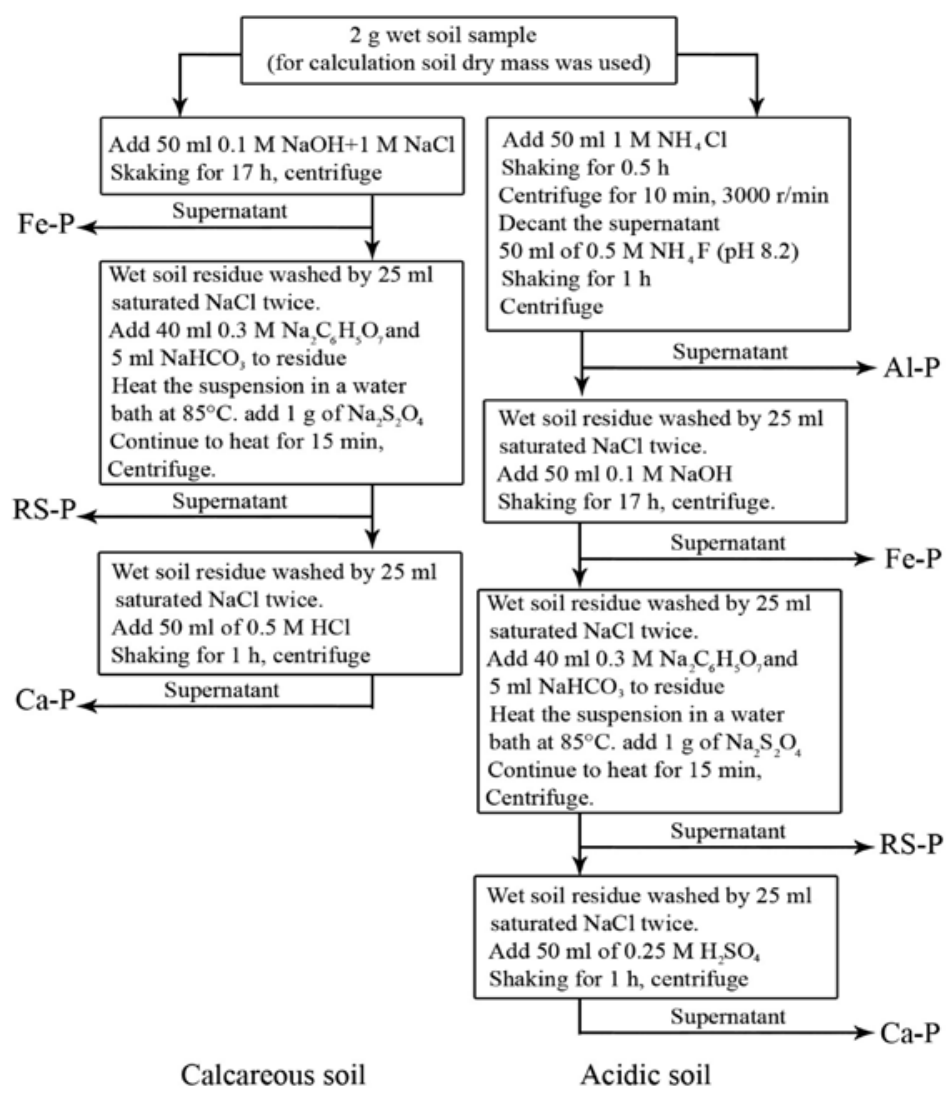

Figure 1. Scheme of sequence extraction of $P$ in calcareous and acidic soils.

\subsection{Statistical analysis}

The experiment was performed as a $4 \times 3 \times 2$ factorial experiment in a completely randomized design (CRD), with three replicates. Statistical analysis of data including normality test, analysis of variance (ANOVA), and comparisons of means was performed using SAS program (SAS Institute, 2002). The comparison of means was carried out using Duncan's multiple range tests at $P<0.05$. Moreover, Pearson correlation and multivariate regression (Stepwise) between parameters was performed by using SPSS program (SPSS 2007).

\section{Results and discussions}

3.1 Effects of phosphorus and organic fertilizers on phosphorus fractions in calcareous soil

Treatment effects on Fe-P fraction in calcareous soil

The amount of Fe-P fraction in calcareous was very low in comparison with acidic soil. Samadi and Gilkes (1999) were reported that Fe-P is an inferior source of $\mathrm{P}$ for plant growth in some Australian calcareous soils. The ANOVA results in calcareous soil showed that major effects (PF and DR) $(p<0.01)$ and interac- 
tion effect $(\mathrm{PF} \times \mathrm{DR} \times \mathrm{OF})(p<0.05)$ significantly influenced on Fe-P fraction (Table 3). Despite the greater solubility of DAP fertilizer, Fe-P concentrations of TSP was higher than DAP fertilizer (Figure 2a). It can be related to Fe impurities of TSP fertilizer. Furthermore, Fe-P concentration significantly increased with increasing of DR of PF (Figure 2b). Based on DR 20 $\mathrm{mg} \mathrm{kg}^{-1}$ treatment had maximum concentration of FeP. Moreover, comparison of mean for the interaction effect between PF $\times$ DR $\times$ OF on Fe-P showed the $\mathrm{TSP}+\mathrm{DR} 20 \mathrm{mg} \mathrm{kg}^{-1}+\mathrm{CDM}$ and DAP + DR $0 \mathrm{mg}$ $\mathrm{kg}^{-1}+$ MSWC treatments contained the maximum and minimum levels of Fe-P fraction in calcareous soil, respectively (Table 4).

\section{Treatment effects on Rs-P fraction in calcareous soil}

The results of ANOVA in calcareous soil showed that major effects of DR $(p<0.01)$ and OF $(p<0.05)$ significantly influenced on RS-P fraction (Table 3). Based on, increasing of PF significantly increased RS-P. The maximum and minimum concentration of RS-P were observed in DR $30 \mathrm{mg} \mathrm{kg}^{-1}$ and $0 \mathrm{mg} \mathrm{kg}^{-1}$ treatments, respectively (Figure 2c). Moreover, application of CDM and MSWC increased RS-P concentration by 41 and $25 \%$ in calcareous soil, respectively (Figure 2d). However, significant difference was only observed between CDM and non-OF treatments.

If reduction of $\mathrm{Fe}^{3+}$ to $\mathrm{Fe}^{2+}$ occurred during the soil-dung incubation, the enhanced solubility of $\mathrm{Fe}$ would have led to increases in exchangeable $\mathrm{Fe}$ in the soil after incubation (Agbenin and Igbokwe, 2006). This act can be associated with increasing of RS-P in calcareous soil. Among the inorganic P fractions in calcareous soil, only RS-P significantly ( $\mathrm{r}=0.59$ and $p<0.01$ ) correlated to soil Olsen-P (Table 6). Shariatmadari et al. (2008) were reported that RS-P signifi- cantly correlated to soil available P (Olsen-P). Willet (1989) also showed that ferric oxide reduction was the dominant source of P released during flooding.

Treatment effects on Ca-P fraction in calcareous soil

Ca-P was the dominant $\mathrm{P}$ fraction in the calcareous soil. Shen et al. (2004) were reported that the dominant total inorganic $\mathrm{P}$ fraction in the calcareous soil at the long-term field trial was Ca-P (69-71\% of total inorganic $\mathrm{P})$. The ANOVA results showed that interaction effect between $\mathrm{PF} \times \mathrm{OF}$ was significant $(p<0.05)$ on Ca-P fraction (Table 3). The maximum and minimum concentration of Ca-P were observed in the $\mathrm{DAP}+\mathrm{MSWC}$ and DAP+ non-OF treatments, respectively (Figure 2e). Moreover, application of OFs with TSP fertilizer was not effective; whereas, Ca-P levels were significantly higher after application of CDM or MSWC with DAP fertilizer in soil. Based on the nonOF treatment recorded significantly lowest $\mathrm{P}$ content and application of CDM and MSWC increased Ca-P concentrations by about 12 and $13 \%$ of in calcareous soil, respectively. Halajnia et al. (2009) were reported that organo-metal complexes were involved in the inhibition of Ca-P precipitation. Robinson and Sharpley (1996) reported the high Ca contents of some animal manure could enhance $\mathrm{PO}_{4}$ sorption capacity of soils by the formation of $\mathrm{Ca}-\mathrm{P}$ precipitates and complexes. MSWC has been reported to effectively supply $\mathrm{P}$ to soil with soil $\mathrm{P}$ concentration increasing with increasing application rates (Hargreaves et al., 2008). In general, on calcareous soils, Ca-P are the predominate pool of soil $\mathrm{P}$ and their solubility is not directly influenced by redox reactions (Sah and Mikkelsen, 1986).

Ca-bound $\mathrm{P}$ in calcareous soils is in three pools, namely dicalcium phosphate $\left(\mathrm{Ca}_{2}-\mathrm{P}\right)$, octacalcium phosphate $\left(\mathrm{Ca}_{8}-\mathrm{P}\right)$, and, apatite type $\left(\mathrm{Ca}_{10}-\mathrm{P}\right)$ equiv- 
alents (Shariatmadari et al., 2007). Results of Shen et al. (2004) showed that Olsen-P was significantly correlated with $\mathrm{Ca}_{2}-\mathrm{P}$ and $\mathrm{Ca}_{8}-\mathrm{P}$, but it had not significant correlate with $\mathrm{Ca}_{10}-\mathrm{P}$. Probably, lack of significant relationship between Ca-P and Olsen-P can be explained by this object, which $\mathrm{Ca}_{10}-\mathrm{P}$ was dominant form of $\mathrm{Ca}-\mathrm{P}$ in calcareous soil, while, $\mathrm{Ca}_{2}-\mathrm{P}$ (readily used by rice plant) was very low.

Treatment effects on Olsen-P fraction in calcareous soil

The ANOVA results showed that all of major effects $(\mathrm{PF}, \mathrm{DR}$ and $\mathrm{OF})$ and interaction effects $(\mathrm{PF} \times \mathrm{DR}$, $\mathrm{PF} \times \mathrm{OF}, \mathrm{OF} \times \mathrm{DR}$ and $\mathrm{PF} \times \mathrm{DR} \times \mathrm{OF})$ were significant $(p<0.01)$ (Table 3$)$. The comparison of mean results showed that the Olsen-P concentration in DAP fertilizer significantly was higher in comparison with TSP (Figure 2f). Furthermore, the Olsen-P concentration with increasing amounts of PFs increased. PF with DR $30 \mathrm{mg} \mathrm{kg}^{-1}$ treatment had maximum level of Olsen-P fraction in comparison with other treatments (Figure 2g). Moreover, there was no significant difference in Olsen-P concentration between non-fertilizer, DR 10 and $20 \mathrm{mg} \mathrm{kg}^{-1}$ treatments.

Olsen-P concentration in calcareous soil was higher in CDM in comparison with MSWC and non-OF treatments (Figure $2 \mathrm{~h}$ ). It can be related to the higher content of available P (more $>4 \mathrm{x}$ ) in CDM (Table 2). Of course, promoting microbial activity is the other reason. Bhattacharyya et al. (2005) were reported that total and Olsen extractable P in MSWC were considerably higher than soil but lower than CDM. Olsen-P significantly increased with increasing of DR. Based on DAP with DR $30 \mathrm{mg} \mathrm{kg}^{-1}$ treatment had maximum concentration of Olsen-P in comparison with other treatments (Figure 2i).
The results of comparison of means for the interaction effect between PF $\times$ OF showed that DAP $+\mathrm{CDM}$ treatment had maximum concentration of Olsen-P in comparison with other treatments (Figure 2j). Xie et al. (1991) observed that Olsen-P content was considerably higher in treatments with animal fertilizer. This high content of Olsen-P can be related to added $\mathrm{P}$ by animal fertilizer and reducing $\mathrm{P}$ adsorption due to competition between phosphate ions and organic molecules (Xie et al., 1991). In addition, the result of comparison of means for interaction effects between $\mathrm{OF} \times \mathrm{DR}$ also showed that $\mathrm{CDM}+\mathrm{DR}$ $30 \mathrm{mg} \mathrm{kg}^{-1}$ treatment had maximum concentration of Olsen-P in comparison with other treatments (Figure $2 \mathrm{k}$ ). In general, addition of the CDM increased the microbial biomass of the soil. The nucleic acids absorbed by clay minerals can be dissolved into the soil solution under submerged conditions with increasing pH (Bhattacharyya et al. 2005). The released nucleic acids may be decomposed by microbes into $\mathrm{P}$ and become available to rice plants (Bhattacharyya et al., 2005). Probably, this act is intensified with increasing of PF. Ultimately, the results of current study were specified treatment of DAP + CDM + DR 30

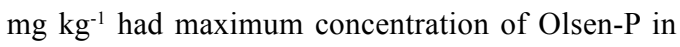
comparison with other treatments (Table 4). This treatment had significant difference with other treatments. Whereas, there were not any significant difference in the other treatments. Halajnia et al. (2009) reported that increases in $\mathrm{P}$ recovery as Olsen-P in the period between 5 to 60 days in PF + cattle manure treatments in calcareous soil can be related to adsorption of $\mathrm{P}$ by organo-metal compounds and precipitation of $\mathrm{P}$ as Ca-P. Olsen $\mathrm{P}$, as a widely used $\mathrm{P}$-availability index in calcareous soils, correlated significantly is only with RS-P fraction (Table 6). 
Table 3. Results of ANOVA to evaluate the effects of phosphorous fertilizer (PF), dose rate (DR) and organic fertilizer (OF) on phosphorous fractions in calcareous soil.

\begin{tabular}{lccccc}
\hline \multirow{2}{*}{ S.o.v. } & df. & \multicolumn{4}{c}{ Mean square } \\
\cline { 3 - 6 } & & Fe-P & RS-P & Ca-P & Olsen-P \\
\hline Phosphorous fertilizer (PF) & 1 & $40.84^{* *}$ & 64.67 & 26.984 & $326.02^{* *}$ \\
Dose rate (DR) & 3 & $115.37^{* *}$ & $20496^{* *}$ & 426.2 & $354.2^{* *}$ \\
Organic fertilizer (OF) & 2 & 17.08 & $7008.8^{*}$ & 821.6 & $340.87^{* *}$ \\
PF $\times$ DR & 3 & 7.44 & 2843.8 & 246.63 & $312.39^{* *}$ \\
PF $\times$ OF & 2 & 4.45 & 3405.9 & $2204.3^{*}$ & $346.96^{* *}$ \\
OF $\times$ DR & 6 & 7.58 & 2887 & 143.21 & $341.24^{* *}$ \\
PF $\times$ DR $\times$ OF & 6 & $13.43^{*}$ & 3054.9 & 375.55 & $326.67^{* *}$ \\
Error & 48 & 5.57 & 1462.8 & 560.3 & 33.34 \\
CV & & 21.32 & 10.06 & 12.54 & 11.14 \\
\hline
\end{tabular}

${ }^{*}$ and ${ }^{* *}$ significant at $p<0.05$ and $p<0.01$, respectively. Iron phosphorous (Fe-P), reductant soluble phosphorous (RS-P), Calcium phosphate (Ca-P) and available phosphorous (Olsen-P).

Table 4. Interaction between type and dose rate (DR) of phosphorous fertilizer (PF) and organic fertilizer (OF) on iron phosphorous (Fe-P) and available phosphorous (Olsen-P) fractions.

\begin{tabular}{|c|c|c|c|c|c|c|c|c|}
\hline \multicolumn{5}{|l|}{ Fe-P } & \multicolumn{4}{|c|}{ Olsen-P } \\
\hline \multirow{2}{*}{$\begin{array}{l}\text { Phosphorous } \\
\text { fertilizer }\end{array}$} & \multirow{2}{*}{$\begin{array}{l}\text { Dose rate } \\
\left(\mathrm{mg} \mathrm{kg}^{-1}\right)\end{array}$} & \multicolumn{3}{|c|}{ Organic fertilizer } & \multirow{2}{*}{$\begin{array}{c}\text { Dose rate } \\
\left(\mathrm{mg} \mathrm{kg}^{-1}\right)\end{array}$} & \multicolumn{3}{|c|}{ Organic fertilizer } \\
\hline & & None & CDM & MSWC & & None & CDM & MSWC \\
\hline \multirow{4}{*}{$\begin{array}{l}\text { Di-ammonium } \\
\text { phosphate }\end{array}$} & 0 & $2.18 \mathrm{~g}$ & $2.17 \mathrm{~g}$ & $1.85 \mathrm{~g}$ & 0 & $49.5 \mathrm{~b}$ & $49.5 \mathrm{~b}$ & $49.4 \mathrm{~b}$ \\
\hline & 10 & $4.92 \mathrm{c}-\mathrm{g}$ & $3.1 \mathrm{e}-\mathrm{g}$ & $2.44 \mathrm{~g}$ & 10 & $49.6 \mathrm{~b}$ & $49.9 \mathrm{~b}$ & $50.1 \mathrm{~b}$ \\
\hline & 20 & $9.29 \mathrm{ab}$ & $3.06 \mathrm{fg}$ & $5.69 \mathrm{~b}-\mathrm{f}$ & 20 & $49.8 \mathrm{~b}$ & $49.9 \mathrm{~b}$ & $49.1 \mathrm{~b}$ \\
\hline & 30 & $5.32 \mathrm{c}-\mathrm{g}$ & $7.96 \mathrm{a}-\mathrm{c}$ & $3.98 \mathrm{~d}-\mathrm{g}$ & 30 & $49.8 \mathrm{~b}$ & $104.7 \mathrm{a}$ & $49.4 \mathrm{~b}$ \\
\hline \multirow{4}{*}{ Triple superphosphate } & 0 & $2.18 \mathrm{~g}$ & $2.17 \mathrm{~g}$ & $1.85 \mathrm{~g}$ & 0 & $49.5 \mathrm{~b}$ & $49.5 \mathrm{~b}$ & $49.4 \mathrm{~b}$ \\
\hline & 10 & $6.97 \mathrm{~b}-\mathrm{e}$ & $3.07 \mathrm{fg}$ & $3.04 \mathrm{fg}$ & 10 & $50.5 \mathrm{~b}$ & $49.1 \mathrm{~b}$ & $48.9 \mathrm{~b}$ \\
\hline & 20 & $7.8 \mathrm{a}-\mathrm{d}$ & $11.52 \mathrm{a}$ & $6.53 \mathrm{~b}-\mathrm{f}$ & 20 & $50.1 \mathrm{~b}$ & $49.6 \mathrm{~b}$ & $49.3 \mathrm{~b}$ \\
\hline & 30 & $7.75 \mathrm{a}-\mathrm{d}$ & $9.3 \mathrm{ab}$ & $7.86 \mathrm{a}-\mathrm{c}$ & 30 & $50.1 \mathrm{~b}$ & $50.3 \mathrm{~b}$ & $49.9 \mathrm{~b}$ \\
\hline
\end{tabular}

Means, in each column, with similar letters are not significantly different at $p<0.05$ using Duncan multiple range test. C-g= cdefg; CDM- cow dung manure; MSWC- municipal solid waste compost; Fe-P - Iron phosphorous; Olsen-P - available phosphorous. 
$\mathbf{a}$

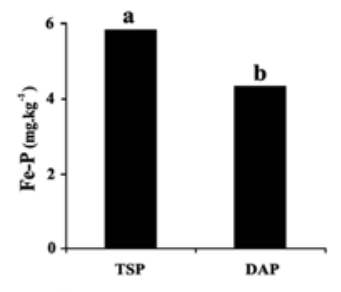

b

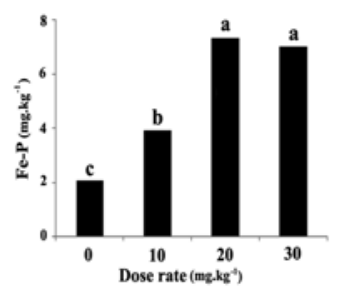

c

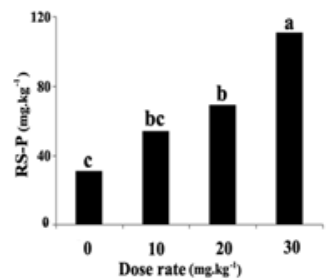

$\mathbf{e}$
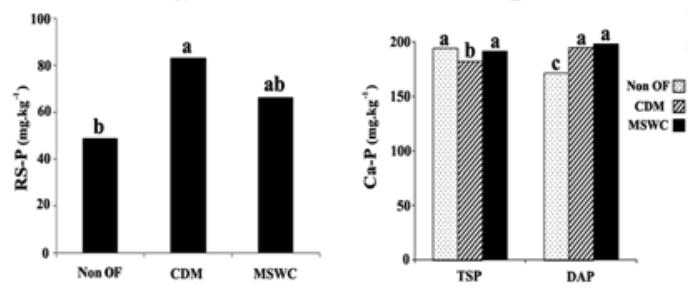

f

g

h
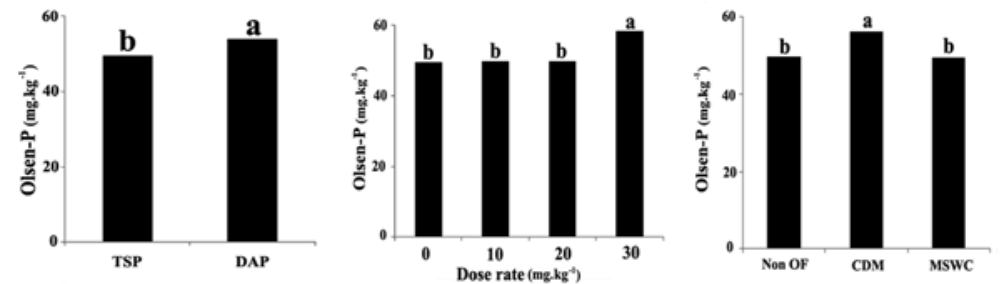

i

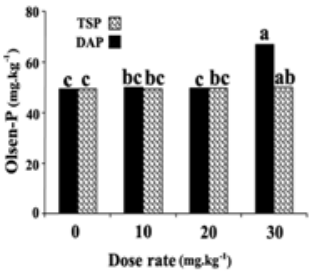

j

$\mathbf{k}$

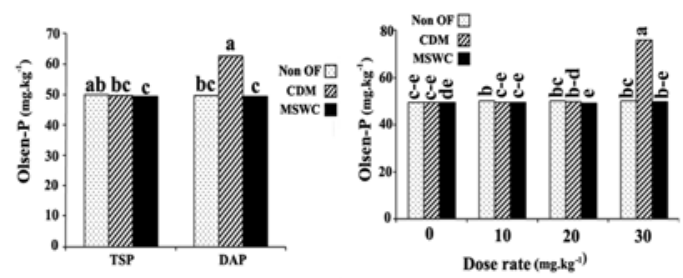

Figure 2. Effects of a- phosphorous fertilizer (PF), b- dose rate (DR)s of PFs on iron phosphorous (Fe-P); effects of c- DRs of PFs and d- Organic fertilizer (OF)s on reductant soluble phosphorous (RS-P); effects of e- PFs and OFs on calcium phosphorous (Ca-P); and effects of f- PFs, g- DRs of PFs, h- OFs, i- type and DRs of PFs, j- PFs and OFs, $\mathrm{k}$ - type and DRs of PFs and OFs on available phosphorous (Olsen-P). Similar letters are not significantly different at $p<0.05$ using Duncan multiple range test. CDM- cow dung manure; MSWC- municipal solid waste compost. 
Effects of phosphorus and organic fertilizers on phosphorus fractions in acidic soil

In the current study, acidic soil treatments only significantly $(p<0.05)$ influenced on Fe-P and RS-P fractions (Table 5). The Ca-P was dominant $\mathrm{P}$ fraction in the calcareous soil, but amount of $\mathrm{Ca}-\mathrm{P}$ was significantly lower than in acidic soil. Furthermore, Olsen-P concentration in acidic soil was significantly higher than in calcareous soil. It can be related to the higher clay content in calcareous soil (Table 1). The edge faces of clay minerals behave similar to the $\mathrm{Fe}$ and $\mathrm{Al}$ hydroxides in the adsorption of $\mathrm{P}$ (Prasad and Power, 2000). Al-P concentration in acidic soil similar to the Fe-P was higher than in calcareous soil, but differences of Al-P concentration were not statistically significant.

\section{Treatment effects on Fe-P fraction in acidic soil}

The ANOVA results showed that DR of PFs had significant effect $(p<0.05)$ on Fe-P in acidic soil (Table $5)$. Based on treatments with DR $10 \mathrm{mg} \mathrm{kg}^{-1}$ had maximum level of Fe-P fraction (Figure 3a). Furthermore, interaction effects between $\mathrm{PF} \times \mathrm{DR}$ had significant effect $(p<0.05)$ on Fe-P fraction (Table 5). The comparison of mean for OF $\times$ DR effect (Figure $3 b$ ) showed that the DR $10 \mathrm{mg} \mathrm{kg-1}$ without OF had maximum level of Fe-P, which can be related to higher $\mathrm{P}$ content in DR $10 \mathrm{mg} \mathrm{kg}^{-1}$. Application of MSWC and CDM significantly decreased Fe-P concentration in DR $10 \mathrm{mg} \mathrm{kg}^{-1}$ treatment. Chang et al. (2004) reported that compost application decreased the residual $\mathrm{P}$ and $\mathrm{Fe}-\mathrm{P}$ fractions, while, the contents of Al-P and Ca-P did not change much.

Result of this study also showed that Fe-P was the dominant $\mathrm{P}$ fraction in the acidic soil. Fe-P was available fractions for plant in acidic soil. In acidic soils, the original superficial, loosely bound phosphates (Fe and Al oxides, available to plant) are converted gradually via a re-precipitation process into highly crystalline Fe-P and Al-P (not available to plant) (Chang et al., 2004). A significant correlation was observed between Fe-P and Olsen-P $(\mathrm{r}=0.30, P<0.05)$ (Table 6). The Al-P and Fe-P pools are expected to have very low bioavailability but can be used by plants when available soil $\mathrm{P}$ is severely depleted (Shen et al. 2004). Results of Singlachar and Samaniego (1973) also showed that the Fe-P fraction was main and most important source of $\mathrm{P}$ absorbed by rice due to high content of $\mathrm{Fe}-\mathrm{P}$ in acidic soils. It was also evident that $\mathrm{P}$ added to soils was slowly converted into Fe-P fraction in submerged soil. Transformation of soil phosphate seemed to be greatly affected by the presence of plant roots. Organic acid exudations (citrate, malate and oxalate) by the roots and decay of organic matter can be reacted with iron and aluminum hydroxides and prevented from $P$ precipitation (Ligaba, 2004). However, in the calcareous soils, Fe-P was not clearly depleted with time by rice, and was not significantly correlated to Olsen-P (Shen et al., 2004). Results indicated that Fe-P had a significant correlation $(\mathrm{r}=0.37$ and $p<0.01$ ) with Al-P in acidic soil (Table 6). Most of the $\mathrm{P}$ added through mineral fertilizers to acidic soils gradually reacts with $\mathrm{Fe}$ and $\mathrm{Al}$ compounds and is transformed into relatively insoluble $\mathrm{P}$ compounds (Verma et al., 2005).

\section{Treatment effects on Rs-P fraction in acidic soil}

The result of comparison of mean for major effect of OF on RS-P (Figure 3c) showed that application of CDM and MSWC increased RS-P in acidic soil. Based on the non-OF treatment had lowest concentration of RS-P and application of CDM and MSWC increased RS-P concentration by about 9.8 and $27.5 \%$ in acidic soil, respectively. However, significant difference was found between non-OF and MSWC treatments. 
Increase in RS-P fraction after adding of CDM and MSWC in acidic soil may explain this observation. It may be possible that organo-metal complexes mainly, $\mathrm{Al}, \mathrm{Fe}$ and $\mathrm{Mn}$, remove $\mathrm{P}$ from solution and reduce the amount of $\mathrm{P}$ loss via runoff and leaching by formation of a cationic bridge between the organic $\mathrm{C}$ and $\mathrm{P}$ (Leytem and Westermann, 2003). The reduction of free hydrous Fe oxides during flooding, and the liberation of sorbed and coprecipitated P increased the levels of extractable P in flooded acidic soil (Willet, 1989). An increase in $\mathrm{pH}$, in fact, favors $\mathrm{P}$ desorption from clay, iron and aluminum oxides. Such $\mathrm{pH}$ changes were, however, found to favor desorption of freshly applied P only (Willet 1989). Organic matter in soil may also have an important effect on ferric iron reduction through its promoting influence on the bacterial activity in flooded soil. MSWC contain appreciable amount of humus C (Bhattacharyya et al., 2005). Humus and humus-forming materials can also help to decrease fixation of phosphate ions on iron and aluminium oxides, which would maintain a steady availability of phosphates to plants (Bhattacharyya et al., 2005).

Table 5. Results of ANOVA to evaluate the effects of phosphorous fertilizer (PF), dose rate (DR) and organic fertilizer (OF) on Phosphorous fractions in Acidic soil.

\begin{tabular}{lcccccc}
\hline \multirow{2}{*}{ S.O.V. } & \multirow{2}{*}{ df. } & \multicolumn{5}{c}{ Mean square } \\
\cline { 3 - 7 } & & Al-P & Fe-P & RS-P & Ca-P & Olsen -P \\
\hline Phosphorous fertilizer (PF) & 1 & 0.019 & 2636.7 & 1755.78 & 0.688 & 153.86 \\
Dose rate (DR) & 3 & 158.24 & $3349.78^{*}$ & 6002.99 & 38.18 & 644.77 \\
Organic fertilizer (OF) & 2 & 105.1 & 2751.88 & $21540^{*}$ & 56.8 & 1289.66 \\
$\mathrm{PF} \times \mathrm{DR}$ & 3 & 154.34 & 2196.7 & 2271.58 & 1.09 & 1298.58 \\
$\mathrm{PF} \times \mathrm{OF}$ & 2 & 0.74 & 3486.87 & 6635.48 & 1.93 & 348.36 \\
$\mathrm{OF} \times \mathrm{DR}$ & 6 & 53.46 & $3059.5^{*}$ & 9432.66 & 94.62 & 1328.79 \\
$\mathrm{PF} \times \mathrm{DR} \times \mathrm{OF}$ & 6 & 85.12 & 1956.9 & 5724.23 & 1.07 & 261.11 \\
Error & 48 & 171.36 & 57589.7 & 4336.11 & 21.1 & 6776.9 \\
$\mathrm{CV}$ & & 8.35 & 16.78 & 18.53 & 16.1 & 18.42 \\
\hline
\end{tabular}

* significant at $p<0.05$. Aluminium phosphorous (Al-P), iron phosphorous (Fe-P), reductant soluble phosphorous (RS-P), calcium phosphate (Ca-P) and available phosphorous (Olsen-P).

Table 6. Coefficients of correlation ( $\mathrm{r}$ ) between different phosphorus fractions and Olsen-P in calcareous and acidic soils.

\begin{tabular}{lccccccccc}
\hline & \multicolumn{4}{c}{ Calcareous soil } & \multicolumn{5}{c}{ Acidic soil } \\
\hline phosphorus fractions & Fe-P & RS-P & Ca-P & Olsen-P & Fe-P & RS-P & Ca-P & Olsen-P & Al-P \\
\hline Fe-P & 1 & $0.46^{* *}$ & -0.16 & 0.11 & 1 & -0.22 & $0.28^{*}$ & $0.30^{*}$ & $0.37^{* *}$ \\
RS-P & & 1 & 0.164 & $0.59^{* *}$ & & 1 & 0.17 & $-0.27^{*}$ & $-0.54^{* *}$ \\
Ca-P & & & 1 & 0.33 & & & 1 & $0.38^{* *}$ & $0.25^{*}$ \\
Olsen-P & & & & 1 & & & & 1 & $0.67^{* *}$ \\
\hline
\end{tabular}

* and ${ }^{* *}$ significant at $p<0.05$ and $p<0.01$, respectively. Degree of freedom (df) for all of phosphorus fractions is 71. 

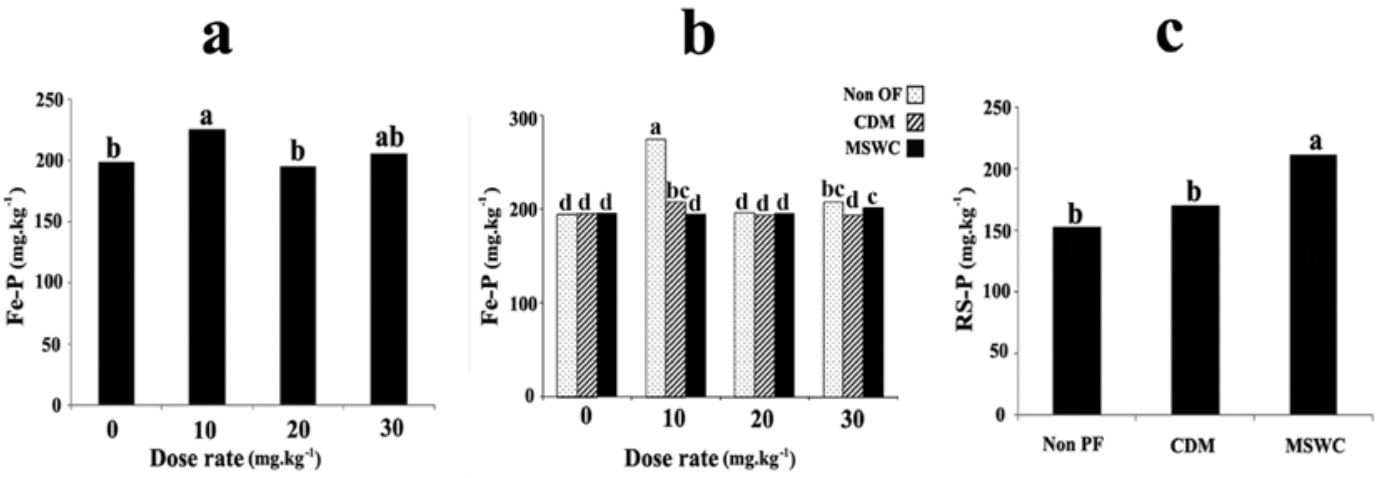

Figure 3. Effects of a- dose rate (DR) of phosphorous fertilizer (PF), b- DR of PF and organic fertilizer (OF) on iron phosphorous (Fe-P); c- effects of OF on reductant soluble phosphorous (RS-P). Similar letters are not significantly different at $p<0.05$ using Duncan multiple range test. CDM- cow dung manure; MSWC- municipal solid waste compost.

\section{Conclusion}

The results of this study showed that $\mathrm{Ca}-\mathrm{P}$ was the predominant form of $\mathrm{P}$ in calcareous soil while, Fe-P and Al-P were predominate in acidic soils. Furthermore, the application of OF significantly increased RS-P and Olsen-P fractions in calcareous soil and RS-P fraction in acidic soil. DAP is suitable for increasing the Olsen-P content in calcareous soil in combination with the organic fertilizers. In general, $\mathrm{P}$ fractions are considerably influenced by $\mathrm{PF}$ and OF on Fe-P, RS-P, Ca-P and Olsen-P in calcareous soil and Fe-P and RS-P in acidic soil. Furthermore, Organic matter of MSWC and CDM can supply phosphorous to plants either by blocking absorption sites and or by releasing soluble $\mathrm{P}$ with time and they can be useful for calcareous and acidic soils. In conclusion, the results of this study showed that OFs especially CDM alters soil physiochemical properties in a way that elevates the soil solution P level; making it a more efficient source of plant-available P. Finally, it should be noted that application of PF and OF should be planned very carefully in rice production to minimize $\mathrm{P}$ pollution and this requires further research.

Abbreviation: P, phosphorous; PF, phosphorous fertilizer; TSP, triple superphosphate; DAP, di-ammonium phosphate; $\mathrm{OF}$, organic fertilizer; $\mathrm{CDM}$, cow dung manure; MSWC, municipal solid waste compost; Fe-P, iron phosphorous fraction; Ca-P, calcium phosphorous fraction; RS-P, reductant soluble phosphorous fraction; Al-P, aluminum phosphorous fraction; Olsen-P, available phosphorous fraction. 


\section{Acknowledgement}

We appreciate the constructive suggestions of the associate editor and two anonymous reviewers to improve our manuscript. We would like to gratefully thank all the members of the soil science laboratory of faculty of agriculture university of Guilan, for providing the facilities to carry out this work and for their suggestions.

\section{Reference}

Agbenin, J. O., Igbokwe, S. O. 2006. Effect of soildung manure incubation on the solubility and retention of applied phosphate by a weathered tropical semi-arid soil. Geoderma. 133, 191-203.

Begg, C. B. M., Kirk, G. J. D., MacKenzie, A. F., Neue, H-U. 1994. Root-induced iron oxidation and $\mathrm{pH}$ changes in the lowland rice rhizosphere. New Phytol. 128, 469-477.

Bhattacharyya, P., Chakrabarti, K., Chakraborty, A., Nayak, D. C. 2005. Effect of municipal solid waste compost on phosphorous content of rice straw and grain under submerged condition. Archives of Agronomy and Soil Science. 51(4), 363370 .

Chang, h. L., Park, C. Y., Park, K. D., Jeon, W. T., Kim, P. J. 2004. Long-term effects of fertilization on the forms and availability of soil phosphorus in rice paddy. Chemosphere. 56, 299-304.

Halajnia, A., Haghnia, G.H., Fotovat, A., Khorasani, R. 2009. Phosphorus fractions in calcareous soils amended with $P$ fertilizer and cattle manure. Geoderma. 150, 209-213.

Hargreaves, J. C., Adl, M. S., Warman, P. R. 2008. A review of the use of composted municipal solid waste in agriculture. Agriculture, Ecosystems and Environment. 123, 1-14.
Hinsinger, P. 2001. Bioavailability of soil inorganic $\mathrm{P}$ in the rhizosphere as affected by root-induced chemical changes: a review. Plant and Soil. 237, 173-195.

Jalali, M., Ranjbar, F. 2010. Aging effects on phosphorus transformation rate and fractionation in some calcareous soils, Geoderma 155, 101-106.

Knapp, E. P., Herman, J. S., Mills, A. L., Hornberger, G. M. 2002. Changes in the sorption capacity of coastal plain sediments due to redox alteration of mineral surfaces. Appl. Geochem. 17, 387-398.

Kuo, S. 1996. Phosphorus. In: Sparks D.L. (Eds.), Methods of soil analysis, Part 3- chemical methods. Agronomy Monograph, vol. 9. ASA and SSSA, Madison, WI, 869-920.

Leytem, A. B., Westermann, D.T. 2003. Phosphate sorption by pacific northwest calcareous soils. J. Soil Sci. 168, 368-375.

Ligaba, A., Shen, H., Shibata, K., Yamamoto, Y., Tanakamaru, S., Matsumoto, H. 2004. The role of phosphorus in aluminium-induced citrate and malate exudation from rape (Brassica napus). Physiologia plantarum. 120, 575-584.

Prasad, R., Power, J. F. 2000. Soil fertility management for sustainable agriculture. CRC Press LLC. Boca Raton, Florida, USA. 347 P.

Reddy, K. R., Kadlec, R. H., Flaig, E., Gale, P. M. 1999. Phosphorus retention in streams and wetlands: A review, Critical Reviews in Environmental Science and Technology. 29(1), 83-146.

Rhue, R. D., Harris, R. G. 1999. Phosphorus sorption/desorption reactions in soils and sediments. In: Reddy K. R., O’Connor G.A., Schleske C.L. (eds.): Phosphorus biogeochemistry in subtropical ecosystems. Lewis Publishers, Boca Raton. 187-206.

Robinson, J. S., Sharpley, A. N., 1996. Reactions in soils of phosphorus released from poultry litter. Soil Sci. Soc. Am. J. 60, 1583-1588. 
Sah, R. N., Mikkelsen, D. S. 1986. Transformations of inorganic phosphorus during the flooding and draining cycles. Soil. Sci. Soc. Am. J. 50, 62-67.

Saleque, M. A., Naher, U. A., Islam, A., Pathan, A. B. M. B. U., Hossain, A.T.M.S., Meisner, C. A. 2004. Inorganic and Organic Phosphorus Fertilizer Effects on the Phosphorus Fractionation in Wetland Rice Soils. Soil. Sci. Soc. Am. J. 68, 1635-1644.

Samadi, A., Gilkes, R. J. 1999. Phosphorus transformations and their relationships with calcareous soil properties of southern Western Australia. Soil Sci. Soc. Am J. 63, 809-815.

Sanchez, P. A., Uehara, G. 1980. Management considerations for acid soils with high phosphorus fixation capacity. In: F.E. Khasawneh et al. (ed.): The role of phosphorus in agriculture. ASA, CSSA, and SSSA, Madison, WI. 471-514.

SAS Institute. 2002. SAS/STAT User's Guide. In: Version 9.1., SAS Institute Cary, NC.

Shariatmadari, H., Shirvani, M., Dehghan, R. A. 2007. Availability of organic and inorganic phosphorus fractions to wheat in toposequences of calcareous soils. Commun. Soil Sci. Plant Anal. 38, 2601-2617.

Shen, J., Li, R., Zhanga, F., Fan, J., Tang, C., Rengel, Z. 2004. Crop yields, soil fertility and phosphorus fractions in response to long-term fertilization un- der the rice monoculture system on a calcareous soil. Field Crops Research. 86, 225-238.

Singlachar, M. A., Samaniego, R. 1973. Effect of flooding and cropping on the changes in the inorganic phosphate fractions in some rice soils. Plant and Soil, 39, 351-359.

Slaton, N. A., Wilson Jr, C. E., Norman, R. J., Ntamatungiro, S., Frizzell, D. L. 2002. Rice Response to Phosphorus Fertilizer Application Rate and Timing on Alkaline Soils in Arkansas, Agronomy Journal. 94, 1393-1399.

SPSS. 2007. SPSS for Windows, Version 16.0. SPSS Inc., Chicago, Illinois, USA.

Verma, S., Subehia, S.K., Sharma, S.P. 2005. Phosphorous fractions in an acid soil continuously fertilized with mineral and organic fertilizers. Biol. Fertil. Soils. 41, 295-300.

Wiedenhoeft, A. C. 2006. Plant Nutrition, Chelsea House Press, USA. 144 p.

Willet, I. R. 1989. Causes and prediction of changes in extractable phosphorous during flooding. Aust J Soil Res. 27, 45-54.

Xie, R. J., Mackenzi, A. F., Hollaran, I. P. O. 1991 Lignosulfonate Effects on Phosphate Reactions in a Clay Soil: Causal Modeling. Soil Sci. Soc. Am. J. 55(3), 711-716. 